\title{
Molecular Dynamics
}

\section{분자동역학 시뮬레이션 방법 소개}

DOI: $10.3938 /$ PhiT. 21.037

정 영 균

\section{Introduction to Molecular Dynamics Simulation}

Youngkyun JUNG

A brief introduction to molecular dynamics (MD) is given, and the basic MD algorithms are described. As an example of applications of coarse-grained MD, some simulation results for bacterial chromosomes (especially, E. coli) are introduced. Finally, the need for parallel computing is stressed.

\section{들어가는 말}

대장균(Escherichia coli, E. coli)은 쉽게 번식할 뿐만 아 니라 유전적으로 비교적 단순하고 다루기 쉽기 때문에 연구 자들이 가장 선호하는 실험대상으로 우리 몸의 창자에서 쉽 게 발견되는 박테리아(그림 1)이다. 대장균 세포는 일반적으 로 길이가 약 $2.0 \mu \mathrm{m}$ 이고 두께가 약 $0.5 \mu \mathrm{m}$ 인 막대 모양으 로 대장균의 유전정보를 담고 있는 DNA는 대장균 세포 길이 의 약 천 배 정도 긴 약 $4.6 \times 10^{6}$ 개의 염기쌍들로 이루어져 있다(그림 1에서 오른쪽 그림: 막대모양의 대장균 세포를 터 트렸을 때 튀어나온 DNA 모습). 이렇게 작은 세포 내에 어떻 게 자기 몸집보다 천 배 이상 긴 DNA가 들어갈 수 있을까? 그리고 어떻게 좁은 공간에서 세포분열 등과 같은 생물학적 과정들이 착오 없이 진행될 수 있을까? 이러한 질문들에 대 한 대답은 현재 괄목할 만한 발전을 이룬 나노기술 덕분에 단일분자 수준에서의 실험이 가능해지면서 하나하나씩 풀리 고 있다. 하지만 열적 요동으로 인한 브라운 운동이 지배적인

\section{저자약력}

정영균 박사는 고려대학교 이학박사(2000)로서 워싱턴대학 박사후연구원을 거쳐 2002년부터 한국과학기술정보연구원(KIST) 슈퍼컴퓨팅센터에서 현재 책임연구원으로 재직 중이다. (yjung@kisti. re.kr)

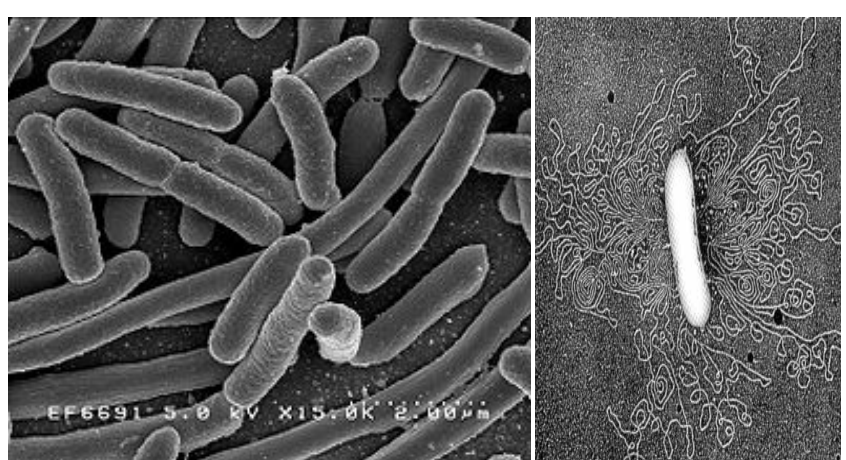

Fig. 1. Escherichia coli bacterium and the chromosomal DNA leaked out of the cell as a continuous molecule that is many times longer than the length of the cell.

나노스케일 세계를 실험으로 탐험하는 일은 그리 녹녹치 않 다. 컴퓨터 시뮬레이션 방법은 나노스케일 세계에서 분자 하 나하나의 거동을 탐험할 수 있는 가장 강력한 연구도구이다.

현재 가장 많이 사용되고 있는 시뮬레이션 방법 ${ }^{[1-3]}$ 에는 molecular dynamics(MD), dissipative particle dynamics(DPD), 그리고 Brownian dynamics(BD) 등이 있는데 이 글에서는 분자동역학 시뮬레이션 방법만 소개하고자 한다. MD 방법에 는 분자를 구성하는 모든 원자들을 고려한 all-atom 모형과 원자들의 자유도를 줄인 coarse-grained 모형이 있다. 원자 수준의 세세한 부분까지 계산할 수 있는 all-atom 모형은 평 균적으로 천에서 백만 개 입자를 다룰 수 있지만 컴퓨팅 자 원의 한계 때문에 $10^{-7}$ 초 정도까지만 계산 가능하다. 이는 세 포 내에서의 운동이나 상호작용이 마이크로 또는 밀리 초 단 위에서 일어난다는 것을 감안하면 세포를 연구하는데 적당치

\section{REFERENCES}

[1] M. P. Allen et al., Computer Simulation of Liquids (Clarendon, Oxford, 1987)

[2] D. Frenkel and B. Smit, Understanding Molecular Simulation (Academic, New York, 2002).

[3] D. C. Rapaport, The Art of Molecular Dynamics Simulation (Cambridge University Press, 2004). 
않은 방법이다. 대신 coarse-grained 모형은 입자의 자유도 를 줄이고 분자를 이루는 입자 개수를 줄일 수 있기 때문에 계산시간을 대폭 줄일 수 있지만 분자에 대한 상세한 정보들 이 빠져있기 때문에 분해능이 많이 떨어지는 단점이 있다. 그 럼에도 불구하고 $\mathrm{MD}$ 방법은 실험을 통해서 밝히기 힘든 물 리현상들을 연구할 수 있는 강력한 연구 방법임에 틀림없다. 이 글에서는 먼저 분자동역학 시뮬레이션 방법을 간략하게 소개하고 이의 응용으로 필자가 최근에 연구하고 있는 박테 리아 염색체의 공간적 구조와 운동 기작을 분자동역학 방법 을 어떻게 적용하여 계산할 수 있는지 설명하고 마지막으로 간략하게 병렬컴퓨팅에 대한 소개를 기술하고자 한다.

\section{분자동역학 시뮬레이션}

분자동역학 시뮬레이션은 다체계 문제(many body prob$\mathrm{lem}$ )를 계산하는 기법 중에 하나로 기본적인 생각은 계를 구 성하는 입자에 작용하는 힘을 계산하고 입자들의 운동방정식 을 반복적으로 풀어서 그들의 위치를 계산하자는 것이다. 즉 어떤 한 순간에 계를 구성하는 입자에 작용하는 힘들을 주어 진 물리법칙에 따라 결정하고 뉴턴의 운동방정식을 이용하여 각 입자들의 위치와 속도 변화를 계산한다. 이렇게 얻어진 새 로운 짜임새(configuration)에 대하여 위의 과정을 반복적으 로 적용하면 계를 구성하는 모든 입자들의 시간에 따른 궤적 을 계산할 수 있다. 이때 가속도는 퍼텐셜에너지의 거리에 대 한 일차 미분인 힘으로부터 계산할 수 있으며 입자들 사이에 작용하는 상호작용은 원자와 분자의 구성에 따라 적절하게 선택하여 사용할 수 있다.

분자동역학 시뮬레이션 과정은 실제 실험실에서 이루어지는 실험과정과 아주 유사하다. 우리가 흔히 보는 실험실에서는 실 험을 위한 샘플을 준비하고, 이를 온도계나 점성도계 등과 같 은 계측기에 연결하여 주어진 시간 동안 관심 물리량을 측정하 고, 많은 샘플로 동일한 실험을 반복하여 통계적 오차를 최대 한 제거한다. 분자동역학 시뮬레이션에서도 실험과 마찬가지로 (i) $N$ 개 입자로 구성된 모형 계를 정하고(샘플준비), (ii) 계의 특성이 시간 변화에 무관해질 때까지 뉴턴 운동방정식을 이 용하여 입자들의 위치와 속도 변화를 계산하고(equilibration), (iii) 마지막으로 측정하고자 하는 물리량을 계산한다.

분자동역학 시뮬레이션에서 샘플준비는 모든 입자에 초기 위치와 속도를 할당해 주는 것이다. 입자들의 초기위치는 입 자들이 서로 겹치지 않도록 정해주는 것이 중요하고, 속도는 $[-0.5,0.5]$ 사이 값에서 고르게 분포하도록 할당해 준다. 하 지만 초기 입자들의 평균속도가 0 이 되도록 만들어 주는 것 이 중요하기 때문에 속도 재축척 방법 $[2,3]$ 등을 이용하여 초기
속도분포가 맥스웰 분포를 따르도록 만들어 준다. 이로써 계 산을 위한 초기 환경이 정해지면 본격적으로 각각의 입자들 에게 가해지는 힘을 계산하고 뉴턴의 운동방정식을 적분하여 입자의 위치와 속도 변화를 계산한다.

분자동역학 시뮬레이션에서 대부분의 시간을 차지하는 과 정은 모든 입자들에 작용하는 힘을 계산하는 부분이다. 이는 한 입자에 작용하는 힘을 구하기 위해서는 $N(N-1) / 2$ 개의 모든 입자 쌍에 대해서 거리를 계산해 주어야 하고 입자 수 $N$ 에 따라 계산시간이 증가하기 때문이다. 지금까지 힘 계산 시간을 단축시키기 위한 방법으로 Verlet list, cell list, Verlet+cell list 방법 등이 도입되었는데, 이러한 방법들을 잘 사용하면 계산시간을 $O\left(N^{2}\right)$ 에서 $O(N)$ 까지 줄일 수 있 다. 각각의 방법들에 대해서는 참고문헌 [2]를 참조하면 된다. 설령 분자동역학이 아니더라도 데이터 구조가 복잡한 다른 시뮬레이션 방법에도 이 방법들을 적용하면 계산 시간을 대 폭 줄일 수 있다.

모든 입자들에 작용하는 힘들을 계산하고 나면 입자들의 위치와 속도 변화를 뉴턴의 운동방정식을 적분하여 얻을 수 있다. 운동방정식을 계산하는 부분은 힘 계산 부분과 비교해 서 계산 속도에 크게 영향을 주지 않는 대신, 오랜 시간 동안 연산하는 과정에서 정확한 계산결과를 얻는 것이 중요하다. 따라서 모든 입자들의 궤적을 보다 정확하게 계산할 수 있는 알고리즘을 선택하는 것이 관건인데 적분 과정에서 생기는 수치적 오차를 최소한으로 줄일 수 있는 알고리즘에는 Verlet 알고리즘, 속도-Verlet 알고리즘, predictor-corrector 방법 등이 있다. 현재 가장 많이 쓰이는 방법은 속도를 $O\left(\Delta^{3} t\right)$ 의 정확도로 계산할 수 있는 속도-Verlet 알고리즘이다. 마찬가 지로 적분 알고리즘에 대해 자세히 알고 싶으면 참고문헌 [2] 를 참고하기 바란다.

분자동역학 시뮬레이션을 통해 시간에 따른 입자의 위치와 속도를 얻으면, 이 값들을 이용하여 우리가 계산하고자 하는 물리량들을 계산할 수 있다. 예를 들면, 온도는 $T=\sum v_{i}^{2} / d N$, 운동에너지는 $E_{K}=\sum\left(v_{i}^{2} / 2 N\right)$, 쌍상관함수(pair correlation function)는 $g(r)=\left(2 V / N^{2}\right)<\sum_{i<j} \delta\left(r-r_{i j}\right)>$ 식으로 계산할 수 있다. 여기에서 사용된 관계식들은 무차원 단위를 사용하 여 표현된 식이다.

무차원 단위(reduced MD units)는 분자동역학 시뮬레이션 에서 매우 유용하다. 예를 들면 원자스케일인 나노미터 $10^{-9}$ $\mathrm{m})$ 대신 "1" 근처 값을 사용함으로서 계산을 단순화시킬 수 있을 뿐만 아니라 운동방정식의 형태를 간단한 모양으로 만 들 수 있다. 이러한 이유로 분자동역학에서는 $\sigma, m$, 그리고 $\epsilon$ 을 길이, 질량, 그리고 에너지의 단위로 정의하고 이를 이용 


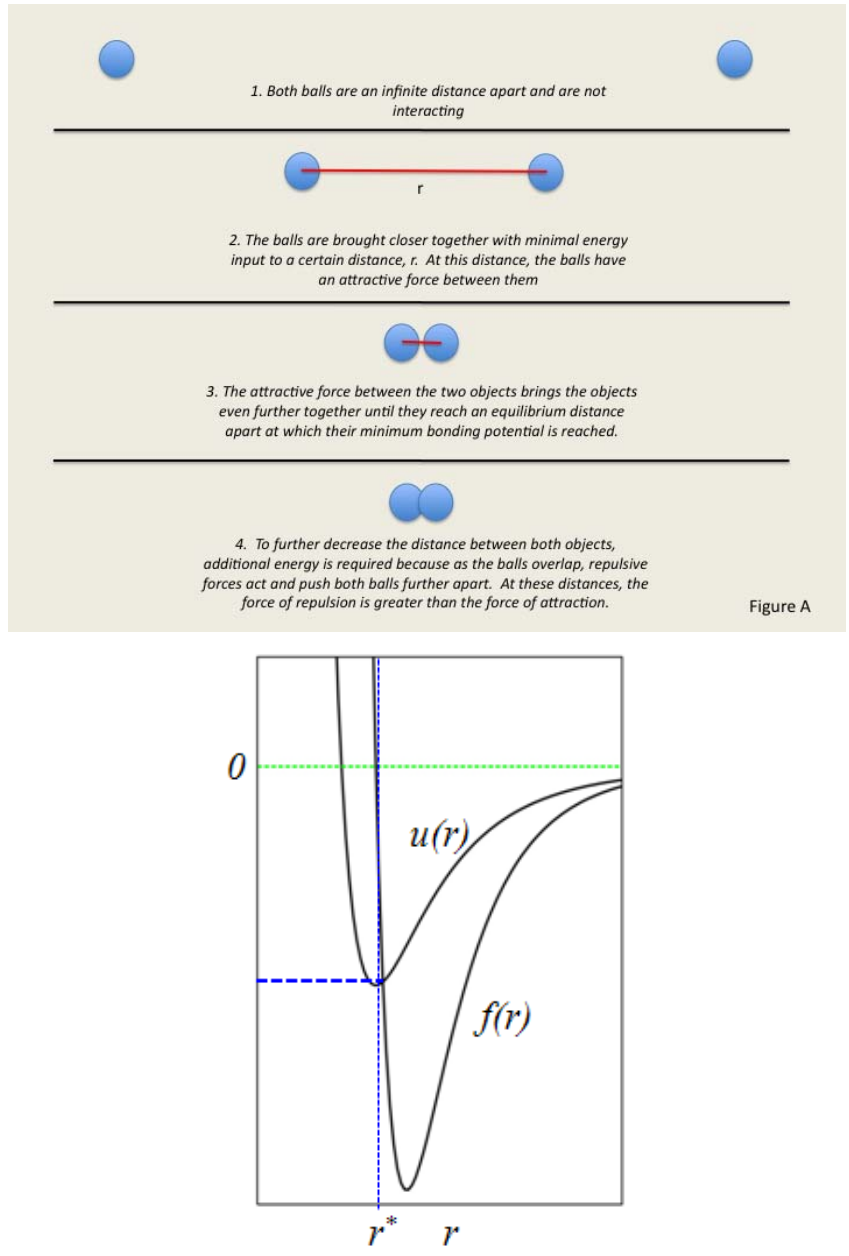

Fig. 2. Intermolecular interactions, the energy of interaction $u(r)$ between two particles as a function of their separation $r$ and the corresponding force $f(r)$.

하여 길이, 에너지, 시간 등을 $r \rightarrow r \sigma, e \rightarrow e \epsilon$, 그리고 $t \rightarrow$ $t \sqrt{m \sigma^{2} / \epsilon}$ 로 표현하여 사용한다. 예를 들어 길이가 $\sigma=3.4 \AA$ 인 아르곤 액체인 경우, 에너지는 $\epsilon=120 \times 1.3806 \times 10^{-16}$ $\mathrm{erg} /$ atom 대신 $\epsilon / k_{\mathrm{B}}=120 \mathrm{~K}$ 로 시간단위는 피코초로 간단히 쓸 수 있다. 만약 계산시간 간격을 $\Delta t=0.005$ 로 정하면 분 자동역학 시뮬레이션을 한번 돌리는데 대략 펨토초가 걸리게 됨을 의미한다.

마지막으로 분자동역학 시뮬레이션에서 사용되는 분자 사 이의 상호작용을 살펴보자. 두 분자 사이의 결합은 분자간 거 리 $r$ 의 함수로 주어지는 퍼텐셜 $u(r)$ 로 기술되고 힘은 퍼텐 셜의 일차 미분으로 표현된다: $f(r)=-d u(r) / d r$. 만약 두 분 자가 멀리 떨어져 있으면 분자 간의 상호작용이 없고, 충분히 가까이 있으면 인력이 작용하고, 너무 가까이 근접하면 두 입 자는 서로 반발하여 밀쳐낸다(그림 2 참조). 통상적으로 퍼텐 셜 모양은 $u(r) \sim r^{-p}$ 로 주어지는데 $p>3$ 이면 단거리 상호작 용, $p \leq 3$ 이면 장거리 상호작용을 한다고 말한다. 고분자와

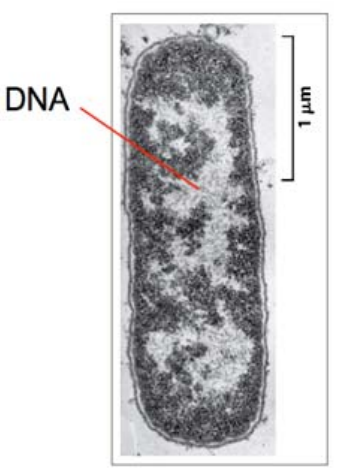

Figure 1-11 Essential Cell Biology (๑ Garland Science 2010)

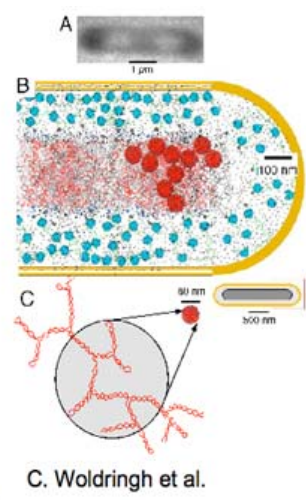

Fig. 3. E. coli cell and DNA compaction in a nucleoid. Red globule represents a negatively supercoiled structural unit which can be regarded as a monomer in MD simulation.

같이 극성이 없는 분자 간의 단거리 상호작용은 비극성분자 간의 약한 상호작용으로 계산할 수 있는데 쌍극자-쌍극자 간 의 인력은 $u(r) \sim 1 / r^{6}$ 로 주어진다. 이러한 이론적 배경에서 레너드-존스(Lennard-Jones, $\mathrm{LJ})$ 퍼텐셜이라고 불리우는 $u(r)$ $=a / r^{12}-b / r^{6}$ 식이 만들어졌다. 여기에서 첫 번째 항은 분자 간의 반발 항으로 컴퓨터의 계산 속도를 향상시키기 위해서 $r^{-12}$ 형태로 임의로 만들어졌다. 즉 $r^{-12}$ 는 $\left(r^{-6}\right)^{2}$ 형태이어 서 컴퓨터에서 계산할 때, 연산속도를 빠르게 해 준다.

분자동역학 시뮬레이션에서 사용되는 $\mathrm{LJ}$ 퍼텐셜은 입자 $i$ 와 $j$ 사이의 거리 $r$ 함수로 $u_{i j}(r)=4 \epsilon\left[(r / \sigma)^{-12}-(r / \sigma)^{-6}\right]$ 로 쓰여지고, 여기에서 $\epsilon$ 과 $\sigma$ 는 에너지와 거리의 척도로서 다루려고 하는 분자의 종류에 따라 달라진다. 첫째 항은 반발 력, 둘째 항은 인력과 관계된다. 고분자와 같이 여러 개의 입 자들이 사슬로 연결되어 있는 경우, 인접한 입자들 사이의 결 합퍼텐셜은 통상적으로 finitely extensible nonlinear elastic (FENE) 퍼텐셜, $u_{F E N E}(r)=-\frac{1}{2} k_{F} r_{0}^{2} \log \left[1-r^{2} / r_{0}^{2}\right]$ 을 사용한 다. 여기에서 $k_{F}$ 는 스프링 상수이고 $r_{0}$ 는 사슬이 유지될 수 있는 최대 길이이다.

\section{박테리아 염색체 시뮬레이션}

서두에서 언급한 것처럼 박테리아 염색체는 자신의 길이보 다 약 천 배나 작은 세포 내에 갇혀 있기 때문에(DNA compaction) 강한 구속력을 받게 된다. 따라서 세포 내에서 염색 체가 공간적으로 어떻게 분포해 있고, confinement에 의해 야기되는 구동력이 무엇이고, 염색체 분열과정에서 confinement가 어떤 역할을 하는가는 세포생물학에서 중요한 질문들 이다. 이 절에서는 필자가 이에 대한 해답을 구하고자 사용했 
던 분자동역학, 특히 coarse-grained MD 적용 방법을 소개 하고 이와 관련된 최근 연구결과를 간단히 소개하고자 한다.

형광 분광학 실험에 의하면 고립된 대장균 염색체는 꼬인 전화선 같은 초나선 형태로 만들어진 독립적인 "구조단위 (structural unit)"로 구성되어져 있고 이러한 초나선 구조가

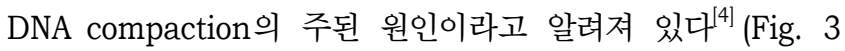
참조. 서로 다른 구조단위는 서로 반발력을 가지고 독립적으 로 움직이기 때문에 구조단위 하나를 독립된 입자로 간주할 수 있다. DNA-결합 단백질들이 국소적으로 DNA에 작용하고 DNA가 사슬형태로 연결된 분자 사슬이라는 특징을 고려하면 이는 훌륭한 매핑이다. 따라서 박테리아 염색체를 구조단위들 로 연결된 고분자로 간주하고(그림 3에서 붉은 공들) 분자동 역학 시뮬레이션을 수행할 수 있다.

열적요동으로 인한 브라운 운동이 지배적인 세포 내의 염 색체는 광장히 큰 자유도를 가지고 모양을 끊임없이 바꾼다. 고분자의 운동을 이해하기 전에, 먼저 용매 안에 있는 구형 입자의 브라운 운동을 간단히 살펴보자. 속도의 상관함수는 $\left\langle V\left(t_{1}\right) V\left(t_{2}\right)\right\rangle=C\left(t_{1}-t_{2}\right)$ 로 시간 $t$ 의 함수로 주어지고 입자 가 속도 $V$ 로 움직이는 경우 운동방정식은 $m d V / d t=-\zeta V$ 로 주어져 완화시간은 $\tau=m / \zeta$ 가 된다. 그러나 입자의 반경이 약 $10 \mathrm{~nm}$ 인 경우 완화시간이 $10^{-10}$ 초로 주어져 실제 고분자 운동의 시간스케일 $10^{-5}$ 초와 비교하면 굉장히 짧은 시간이다. 따라서 고분자 운동을 다룰 때, $\tau \rightarrow 0$ 극한에서 속도 상관함수와 평균제곱거리를 $\langle V(t) V(0)\rangle=2 D \delta(t)$ 와 $\left\langle r(t)^{2}\right\rangle=2 D t$ 로 각 각 쓸 수 있다. 여기에서 $D$ 는 퍼짐상수이다. 또한 브라운 입 자가 퍼텐셜 $u(r)$ 영향 하에서 움직이는 경우, 입자는 평균 속도 $\bar{V}=-(1 / \zeta) d u / d r$ 를 가지고 움직이게 된다. 이 경우 입 자의 변위는 $\tau \rightarrow 0$ 극한에서 랑제방(Langevin) 방정식으로 알 려져 있는 $d x / d t=-(1 / \zeta) d u / d r+g(t)$ 에 따라 움직이게 된 다. 여기에서 $g(t)$ 는 평균속도 근처에서 입자의 요동을 나타 내고 $\langle g(t)\rangle=0,\left\langle g(t) g\left(t^{\prime}\right)\right\rangle=2 D \delta\left(t-t^{\prime}\right)$ 을 따른다.

Coarse-grained MD를 사용하여 박테리아 염색체를 시뮬 레이션하기 위해서 필자는 양끝이 닫힌 실린더에 고분자를 넣고, 고분자는 bead-spring 모형으로, 입자간 상호작용은 레너 드-존스 퍼텐셜과 유사한 Weeks-Chandler-Anderson(WCA) 퍼텐셜을, 두 입자 사이의 결합은 $\mathrm{FENE}$ 퍼텐셜을 사용했다. 위에서 언급된 랑제방 방정식을 이용하여 분자들의 위치와 속도를 계산하면 정준 앙상블(NVT)에서 계의 온도를 일정하 게 유지시킬 수 있다. 앙상블의 종류 및 온도/압력을 유지시 키는 기법은 뒤에서 다른 필자에 의해 자세히 다루어져 있다.

최근 분자동역학 시뮬레이션을 이용하여 필자가 수행한 연 구 결과를 간단하게 소개하면 다음과 같다. (i) 박테리아 세포 염색체는 세포 내에서 스파게티처럼 서로 뒤엉켜 있지 않고

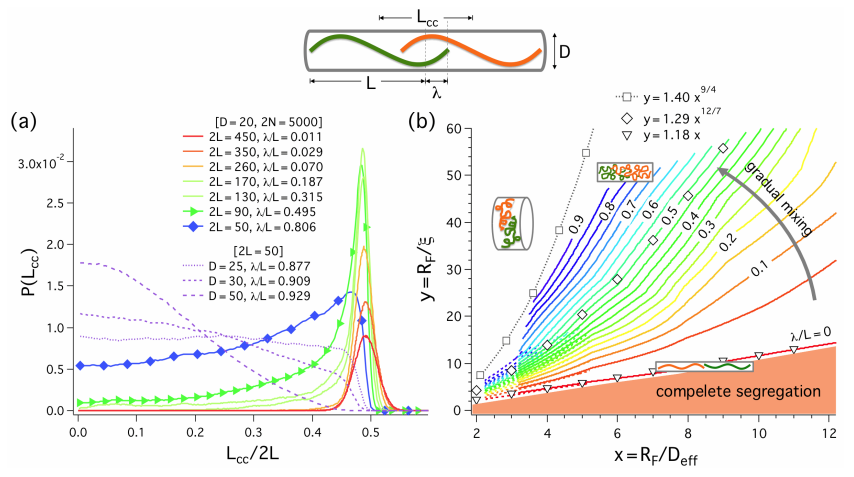

Fig. 4. Distribution of the center-to-center distance $L_{c c}$ of two confined chains $P\left(L_{c c}\right)$ (a) and chain miscibility (b). For the well-segregated cases (solid lines without symbols), $P\left(L_{c c}\right)$ has a narrow peak at $L_{c c} / 2 L \approx 0.5$. On the other hand, $P\left(L_{c c}\right)$ for the much mixed cases (lines with filled diamonds) is broader. In the most miscible case $D / 2 L=1$ (the dashed line in purple); $P\left(L_{c c}\right)$ is a Gaussian distribution centered at $L_{c c}=0$.

선형적으로 분포한다. ${ }^{[5]}$ (ii) 닫힌 실린더에 있는 환형 고분자를 두 개의 선형고분자로 간주하면, 환형고분자는 선형고분자에 비해 탄성계수 값이 다섯 배 이상 크고 자유에너지는 약 두 배 높다. 이는 고분자가 꼬여 있는 것보다 펴져 있기를 선호함을 의미한다. ${ }^{[6]}$ (iii) 충분히 긴 고분자를 사용하는 경우, 완화시간 을 계산하면 unexpected 영역에서 블롭-축적(blob-scaling) 영역으로 교차전이(crossover)가 일어난다. ${ }^{[7]}$ 즉 짧은 고분자 를 사용하는 경우 블롭-축적 이론이나 실험으로 관측되는 임 계지수 값들을 볼 수 없다. ${ }^{[8]}$ (vi) 두 개의 사슬을 닫힌 실린더 에 넣으면 제외부피효과(excluded volume effect)와 사슬 connectivity 때문에 엔트로피가 감소한다. 즉, 엔트로피는 열 역학적 계에서 일로 변환될 수 없는 에너지의 양으로 $S=$ $k_{\mathrm{B}} \log W$ 로 정의되는데 계가 실린더에 갇히면 자유도(중복도, $W$ )가 작아져 엔트로피가 줄어들게 된다. 이 엔트로피 감소는 구속력에 의해 야기되고 두 사슬 간에 작용하는 반발력을 증 가시키는 요인이 되어 사슬이 섞이지 못하게 한다. 세포 분열 과정은 분자동역학 시늉내기 모형에서 두 개 사슬이 얼마나 섞여 있는지를 측정하면 알 수 있는데 최근 공동연구자들과 함께 작성된 miscibility 그림(그림 4. 오른쪽)은 세포의 aspect-ratio와 분자의 밀도를 알면 염색체의 분열 정도를 가늠

\section{REFERENCES}

[4] T. Romantsov, et al., Biophys. J 92, 2875 (2007).

[5] Y. Jung et al., Macromolecules 45, 3256 (2012).

[6] Y. Jung et al., Soft Matter 8, 2095 (2012).

[7] J. Kim et al. (in preparation).

[8] Y. Jung et al., Phys. Rev. E 79, 061912 (2009).

[9] Y. Jung et al., Phys. Rev. E 82, 051926 (2010). 
할 수 있음을 보여준다. ${ }^{[5,6]}$ 그림 4에서 보이는 바와 같이 세포 의 모양이 비등방적(anisotropic)일수록 분열이 잘 일어난다.

\section{병렬컴퓨팅을 이용한 시뮬레이션}

위에서 언급했듯이 시뮬레이션에서 가장 많은 계산시간이 소요되는 부분은 입자에 작용하는 힘을 계산하는 부분이다. 이를 개선하기 위한 다양한 알고리즘들이 개발되었고 사용되 고 있지만 보다 큰 규모의 문제를 풀기 위해서는 병렬컴퓨팅 방법(예, Message Passing Interface, MPI)을 이용하여 수 백 또는 수천 개의 프로세서를 동시에 사용하는 방법을 사용 한다. 하지만 병렬처리를 위해서는 작업을 프로세서마다 분배 하고 매번 모든 프로세서 간에 정보를 교환해야 하기 때문에 프로세서 수가 증가하면 계산시간 이외에 통신에 따른 시간 이 추가로 증가하게 된다. 하지만 병렬컴퓨팅 기법(예, 영역 분할기법, 분자분할기법 등)을 적절히 활용하면 기존에 상상 도 하지 못했던 규모의 문제를 다룰 수 있다. MPI 기법은 단 일 $\mathrm{CPU}$ 를 사용하여 작은 문제를 풀 때에도 사용될 수 있다. 가령 통계적인 오차를 줄이기 위해 많은 앙상블을 필요로 하 는 경우 MPI 기법을 이용하여 독립적인 작업을 여러 대의 컴 퓨터에서 동시에 수행시킬 수 있다. 병렬컴퓨팅 방법을 사용 하기 위해서는 많은 $\mathrm{CPU}$ 가 필요한데 필자가 근무하고 있는 한국과학기술정보연구원의 슈퍼컴퓨팅센터는 300테라플롭스 이상의 컴퓨팅자원을 보유하고 있으며 이를 전략과제 등과 같은 지원프로그램을 통해 연구자들에게 지원하고 있다. 컴퓨 팅 자원이 필요하신 분들은 슈퍼컴퓨팅센터에서 지원하는 다 양한 지원프로그램을 활용할 수 있다.

\section{나가는 말}

박테리아 세포는 진핵세포와 비교해서 매우 간단하지만 상
대적으로 실험으로 관측하기 힘들어 나노테크놀로지가 개발 된 현재에도 염색체의 공간적 구조나 분열 기작을 밝히기에 는 아직 갈 길이 멀다. 이런 상황에서 본 글에서 소개한 분자 동역학 시뮬레이션 방법은 생물물리학에서 문제가 되는 많은 문제들을 해결해 줄 수 있는 강력한 도구가 될 수 있다. 비록 본 글에서는 생물물리학의 일부에 대해서만 언급했지만 분자 동역학 방법의 적용 범위는 물리학, 화학, 화학공학, 재료공 학, 기계공학 등을 망라하며 이는 실험적으로 얻기 힘든 분자 수준에서의 정보들을 제공해 준다. 하지만 분자동역학 시늉내 기 방법이 모든 문제를 해결해 주는 것은 아니다. 예를 들면, 분자동역학 시늉내기를 이용하여 계산할 수 있는 계의 크기 나 시간 스케일이 실제 실험에서의 스케일과 크게 다르다는 것이다.

실험을 구현하기 위해 약 $10^{9}$ 개 이상의 입자수를 고려해야 하지만 실제 $\mathrm{MD}$ 에서는 $10^{4}$ 개 정도의 입자를 다루기에도 쉽 지 않다. 또한 대부분의 물리현상에서 빠르게 일어나는 진동 운동은 $10^{-12}$ 초(피코초) 수준에서 일어나기 때문에 $\mathrm{MD}$ 에서는 시간단위로 보통 $10^{-15}$ 초(펨토 초)를 사용해야 한다. 따라서 $10^{-6}$ 초(마이크로초) 이상에서 일어나는 현상을 시뮬레이션하 기 위해서는 $10^{9}$ 번의 시뮬레이션을 수행해야 한다. 그러나 우 리가 보고자하는 현상들은 대부분 밀리 초에서 수 시간에 이 르는 시간 영역에 걸쳐 있기 때문에 분자동역학 시늉내기 방 법만 사용해서 결과를 얻는다는 것이 불가능하다는 결론이 나온다. 그럼에도 불구하고 분자동역학 시뮬레이션 방법은 미 시세계를 탐험할 수 있는 강력한 연구도구임에 분명하다. 최 근 미시세계에서 분자 하나하나의 거동에서 거시세계의 물리 현상을 시뮬레이션할 수 있는 멀티스케일 모델링(multiscale modeling) 방법들이 개발되고 있다. 이러한 방법들은 지금까 지 다루지 못했던 다양하고 심오한 물리세계를 탐험할 수 있 는 기회를 제공해 줄 것이다. 